\title{
FUNCTIONAL GENES POLYMORPHISM ASSOCIATIONS WITH EGG QUALITY TRAITS IN THE POPULATIONS OF DUAL-PURPOSE CHICKEN LINES OF UKRAINIAN SELECTION
}

\author{
R. O. Kulibaba ${ }^{1}$, M. I. Sakhatskyi ${ }^{1}$, Yu. V. Liashenko ${ }^{2}$, P. S. Yurko ${ }^{3}$, Yu. V. Osadcha ${ }^{1}$ \\ ${ }^{1}$ National University of Life and Environmental Sciences of Ukraine, \\ 15, Heroiv Oborony Str., Kyiv, 03041, Ukraine \\ ${ }^{2}$ The Institute of Animal Science, the National Academy of Agrarian Sciences of Ukraine, \\ 1-A, Tvarynnykiv Str., Kharkiv, 61026, Ukraine \\ ${ }^{3}$ Kharkiv State Zooveterinary Academy of the Ministry of Education and Science of Ukraine, \\ 1, Akademichna Str., smt Mala Danylivka, 62341, Ukraine
}

E-mail:romankx37@gmail.com*,mik99@ukr.net,yurij2303@gmail.com,yurkopolina81@gmail.com,seledat@ukr.net

Received May 04, 2020 / Received June 25, 2020 / Accepted July 20, 2020

\begin{abstract}
Aim. To study the egg quality traits of Poltava Clay chicken line 14 and Rhode-Island Red chicken line 38 with different genotypes of the prolactin gene $(P R L)$, growth hormone gene $(G H)$, growth hormone receptor gene $(G H R)$, insulin-like growth factor I gene $(I G F-I)$ and Mx gene $(M x)$. Methods. The study was conducted using the method of polymerase chain reaction and restriction fragment length polymorphism analysis (PCR-RFLP). Results. We found significant differences in line 14 for egg quality between prolactin, growth hormone, growth hormone receptor and Mx loci. Homozygous individuals CC and TT by prolactin locus prevailed over heterozygotes CT for egg weight on the $30^{\text {th }}$ week of life. As for the growth hormone gene, the maximum differences for egg weight were revealed when comparing $\mathrm{BC}$ heterozygotes with $\mathrm{CC}$ homozygotes. As for the growth hormone receptor gene, significant prevalence $(\mathrm{p}<0.05)$ of individuals with the B0 genotype over A0 by parameters of egg yolk weight was noted at the age of 52 weeks. Significant differences $(\mathrm{p}<0.05)$ in eggshell thickness were determined for genotypes AG and GG by Mx gene in week 52. There were significant differences $(\mathrm{p}<0.05)$ in egg quality traits for prolactin and Mx gene for chickens of line 38. TT homozygotes by prolactin locus are characterized by the prevalence of values $(p<0.05)$ for the egg, yolk and shell weight. In case of Mx gene polymorphism, the heterozygous individuals were characterized by significantly higher values $(\mathrm{p}<0.05)$ of egg and albumen weight on the $30^{\text {th }}$ week of life. There were no significant differences in both experimental chicken lines for other egg quality traits between individuals with different genotypes. Conclusions. The data obtained are recommended for the use in breeding programs for Poltava Clay chicken line 14 and Rhode-Island Red chicken line 38 with the aim of obtaining microlines with the different genotypes for $P R L, G H$, GHR and $M x$ loci.
\end{abstract}

Key words: polymorphism, prolactin, population, chicken, gene, allele, productivity, egg quality.

DOI:

\section{INTRODUCTION}

Most breeding programs are aimed at obtaining economic profit via creating a maximally possible competitive product. In case of poultry breeding, it means breeding to increase the level of egg-laying capacity (number of eggs), quality of eggs (compliance with the standard for brooding and edible eggs) and quality of meat traits. Therefore, the aims of selection work

(C) R. O. KULIBABA, M. I. SAKHATSKYI, Yu. V. LIASHENKO, P. S. YURKO, Yu. V. OSADCHA, 2020 in poultry breeding are defined by the tasks, specified according to the type of productivity trend for poultry - egg-laying, meat, or dual-purpose. Over the last decades, modern DNA-technologies have been actively introduced into poultry selection, which gave rise to marker-assisted (MAS) and genome selection (Wolc et al., 2016). The combination of modern DNA-technologies and classic selection approaches paved the way for the creation of highly productive competitive lines and breeds of poultry (Simrinder et al., 2013). Unfortunately, in this respect the Ukraini- 
an domestic poultry breeding somewhat lags behind novel global tendencies.

Regardless of all the progress, modern selection work is not limited to the use of commercial breeds of chickens only. Promising studies include the ones, using local and indigenous breeds from different regions of the world (Li et al., 2020). In this case, the foundation for breeding work is based on 1) the analysis of the genetic structure of populations of different chicken breeds, and 2) the search for associations between determined polymorphic loci and economic traits (Boschiero et al., 2018; Chethan et al., 2018). It involves the study of both (multiple) single nucleotide polymorphisms (SNP's) and Insertion and deletions (Indels) in the whole genome, and also the polymorphism of specific genes, the functional activity of whose products is related to ensuring the main physiological functions of the organism of animals (Bhattacharya et al., 2011; Heba et al., 2017; Dementeva et al., 2019).

One of the most promising types of marker assisted selection (MAS) in the context of selection with local

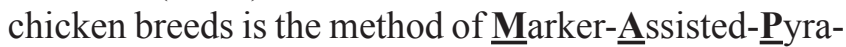
miding (MAP) (Xu et al., 2012). This approach is used for genotyping of birds by the combination of markers (loci), whose allelic variants are associated with the manifestation of similar economic traits. In future, the consistent application of MAP will help to obtain experimental populations of poultry with complex genotypes in terms of gene combinations. In this trend of studies, MAP may be presented as a combination of

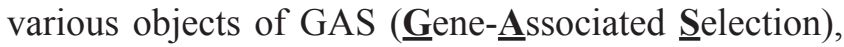
i.e. selection at the level of one functional gene. Modeling of components of gene-associated selection opens rather wide perspectives and is actively used in selection programs of different countries with indigenous and local populations/breeds of chickens. A good illustration for the above mentioned may be found in the studies on polymorphism of genes, whose products are involved in the network of humoral regulation, and whose allelic variants are potentially associated with the manifestation of economic traits (Esmailnejad et al., 2018; Ahmadi et al., 2019; Bello et al., 2020).

The studies on populations and lines of chickens of Ukrainian selection are rather scarce (Kulibaba et al., 2018). Unfortunately, these results are almost not used in national selective genetic programs that leads to gradual withering of the potential of domestic poultry breeding. Therefore, the use of the experience of foreign scientists, actively studying and introducing modern DNA-technologies as an alternative variant in the practice of domestic poultry breeding, is one of urgent tasks of Ukrainian agricultural biology.

The aim of this study was to investigate the relation between egg quality traits of Poltava Clay chicken line 14 and Rhode-Island Red chicken line 38 and different genotypes for the prolactin gene $(P R L)$, growth hormone gene $(G H)$, growth hormone receptor gene $(G H R)$, insulin-like growth factor I gene $(I G F-I)$ and Mx gene $(M x)$. These studies are the continuation of our previous scientific work which was devoted to the study of the population genetic parameters of Ukrainian chicken lines by various DNA-markers. In this article is described the analysis of egg quality traits for two local chicken breeds with different genotypes by several functional genes.

\section{MATERIALS AND METHODS}

The studies were conducted in the laboratory of molecular-genetic and physiological-biochemical research in animal breeding of the Institute of Animal Science, NAAS.

Poltava Clay chicken line $14(\mathrm{n}=100)$ and RhodeIsland Red chicken line $38(\mathrm{n}=100)-$ chickens of Ukrainian selection with dual-purpose productivity (eggs and meat) were used in the studies.

Feathers were used as a source of biological material. The commercial set of reagents DNA-Sorb-B was used to extract DNA according to the manufacturer's instructions (AmpliSens, Russian. https://interlabservice. ru/upload/iblock/318/DNA-sorb-B\%20221217.pdf).

The amplification of fragments of the target genes involved the use of the following primers: prolactin gene (C-2402T) - agaggcagcccaggcattttac and cctgggtctggtttggaaattg (Alipanah et al., 2010); growth hormone gene (4 intron, MspI-polymorphism) - ctaaaggacctggaagaaggg and aacttgtcgtaggtgggtctg (Feng et al., 1997); growth hormone gene (4 intron, AluIpolymorphism) - gagggacgtggttatgggcac and gacctcaaggattgcagggct (Kulibaba et al, 2017); insulin-like growth factor I gene (promoter fragment) - cattgcgcaggctctatctg and tcaagagaagccettcaagc (Khadem et al., 2010); growth hormone receptor gene (2 intron) ggctctccatgggtattagga and gctggtgaaccaatctcggtt (Feng et al., 1997); Mx gene (G2032A, mutation S631N) cettcagcetgtttttctcctttaggaa and cagaggaatctgattgctcaggcgtgta (Luan et al., 2010).

The amplification was conducted by the following programs: 1 cycle - denaturation $94{ }^{\circ} \mathrm{C}, 3 \mathrm{~min} ; 35$ cycles - denaturation $94{ }^{\circ} \mathrm{C}, 45 \mathrm{~s}$, annealing $45 \mathrm{~s}\left(62{ }^{\circ} \mathrm{C}-\right.$ for $P R L ; 61$ and $63{ }^{\circ} \mathrm{C}$ - for $G H ; 55{ }^{\circ} \mathrm{C}$ for $I G F-I$; 
$60{ }^{\circ} \mathrm{C}$ - for $G H R ; 60{ }^{\circ} \mathrm{C}$ - for $M x$ ), elongation $72{ }^{\circ} \mathrm{C}$, $45 \mathrm{~s} ; 1$ cycle - final elongation $72{ }^{\circ} \mathrm{C}, 10 \mathrm{~min}$. The volume of the final mixture was $20 \mu \mathrm{L}$, the concentration of primers $-0.2 \mu \mathrm{M}$ in each case.

PCR-RFLP polymorphism was studied for each locus using the corresponding restriction endonucleases - AluI ( $P R L, G H)$, MspI $(G H)$, HindIII $(G H R)$, HinfI $(I G F-I)$ and RsaI $(M x)$ respectively. The restriction procedure was conducted according to the manufacturer's instructions (Thermo Fisher Scientific, USA).

The electrophoresis of restriction products was done in $3 \%$ agarose gels. Ethidium bromide $(0,5 \mathrm{mkg} / \mathrm{ml})$ was used to visualize fragments under UV light $(254 \mathrm{~nm})$. The sizes of restriction fragments were determined using molecular weight markers M-50 and M-100 (InterLabService, AmpliSens ${ }^{\circledR}$ Biotechnologies, Russian).

The egg quality traits were registered according to Tsarenko (1988) by the following parameters: Ew (Egg weight); Yw (Yolk weight); Aw (Albumin weight); ESw (Egg Shell weight); ESth (Egg Shell thickness) (the average value between the indices of egg shell thickness at the sharp and blunt end of the egg, and in the middle); HU (Haugh unit) (Tsarenko, 1988). The measurements were done when chickens were 30 and 52 weeks old, according to the valuation requirements.

The analysis of associations between different genotypes in terms of each determined polymorphic locus and the investigated egg quality traits was conducted by one-way analysis of variance (ANOVA) and Tukey Kramer Multiple Comparison test as an instrument of post-hoc testing. The calculations were done in Microsoft Excel using Real Statistics Resource Pack (http:// www.real-statistics.com/free-download/real-statisticsresource-pack/). The distribution of sampling data was checked by Kolmogorov-Smirnov test. If the data distribution was reliably different from the normal distribution, the non-parametric Mann-Whitney U test was applied.

\section{RESULTS}

These studies were in line with the general theme of investigating the specificities of genetic variability for chicken populations of Ukrainian selection by the combination of loci of quantitative traits. PCR-RFLP was used to study polymorphism of target loci and determination of the corresponding alleles. The results of typing were used to determine various allelic variants in each investigated locus in the experimental populations of chickens (Figure).
The analysis of the distribution of allelic frequencies and genotypes demonstrated the absence of microevolutional changes in Poltava Clay and Rhode-Island Red chicken populations. The determined loci were polymorphic in each population with several exceptions.

For instance, locus GHR by HindIII-polymorphism in intron 2 of the gene was found to be monomorphic in chicken line 38, which confirmed previously obtained (in the other generation) results (Kulibaba, 2016). At the same time, birds of all the possible genotypes (A0 and B0) were determined within Poltava Clay chicken population. It is noteworthy that contrary to the other investigated loci, growth hormone receptor gene in chicken is related to hemizygous ones, explaining the absence of heterozygous hens. We found different alleles and genotypes in each experimental population by all the other loci.

Taking into consideration the fact that each investigated locus in the populations of earlier generations is presumably in the state of genetic equilibrium, under conditions of absent targeted selection work, indeed a considerable change in the frequency values of alleles and genotypes did not occur according to HardyWeinberg's law in our earlier studies (Kulibaba, 2017). This regularity was also observed in our present study. No significant change in the frequency values of alleles of the investigated loci was noted in different generations which demonstrated complete absence of expressed form-building processes in the populations. The experimental populations of chickens were bred "in themselves", and no reliable differences between frequency values were observed. The results obtained highlight the need for a complex approach in selecting local chicken breeds, which would involve both classic approaches and achievements of novel DNA-technologies. Otherwise, the situation will demonstrate status $q u o$, when the only significant changes in the genetic structure by the combination of QTL are confirmed only on the stage of creating lines, while on the modern stage they are possible only due to different fluctuations (genetic drift) which contradicts the main ideas of breeding as a science, but unfortunately reflects the common trend in Ukrainian poultry breeding.

In any case, the presence of different allelic variants by each investigated locus in experimental populations of chickens helped analyze the association between different genotypes and egg quality traits. It should be noted that the specificities of genetic structure and conditions of keeping birds prevented from analyzing the association between the birds of all the present geno- 

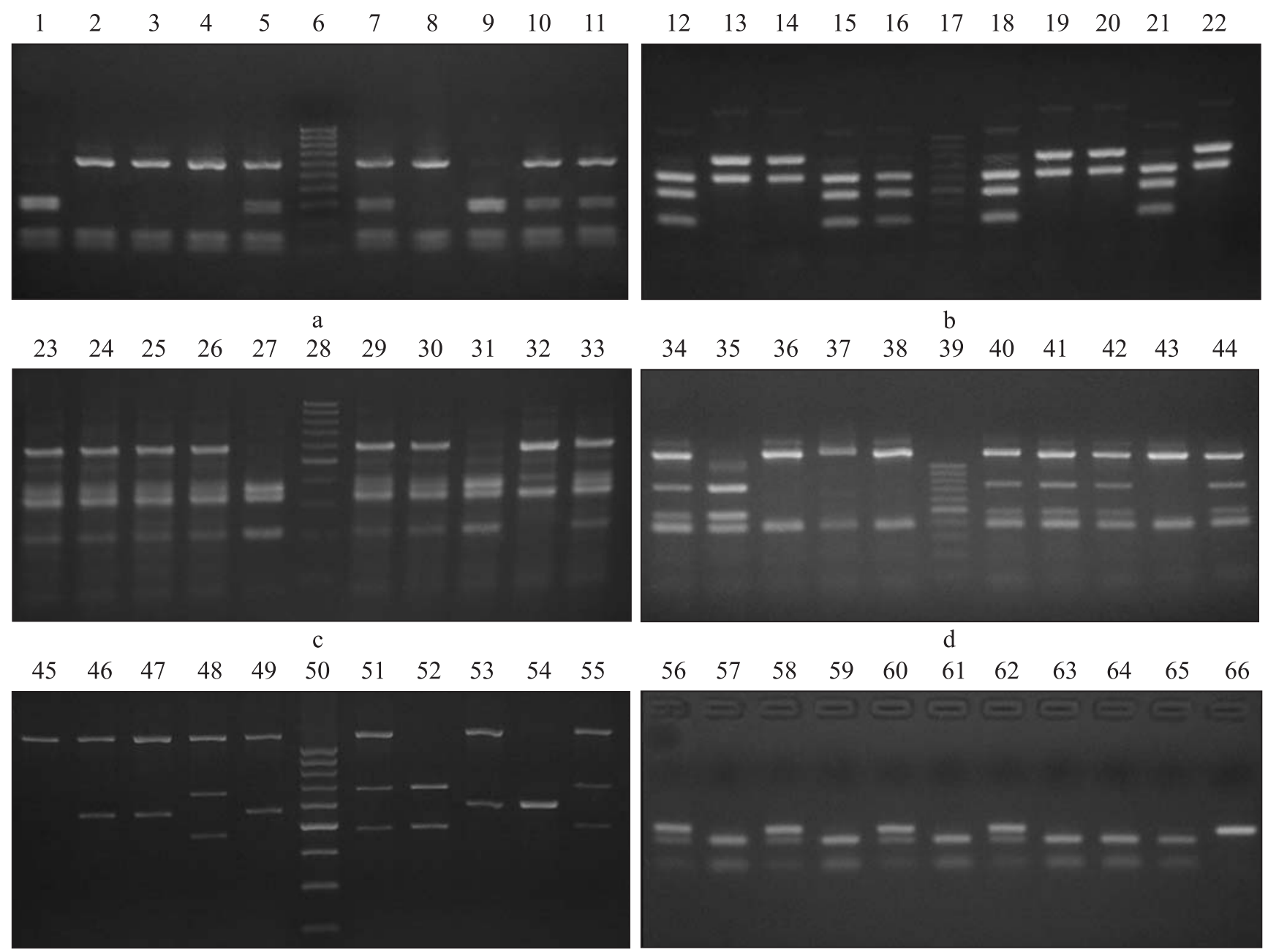

$\mathrm{e}$

$\mathrm{f}$

The electrophoregrams of restriction products: a $-P R L: 1,9-\mathrm{CC}, 2-4,8-\mathrm{TT}, 5,7,10,11-\mathrm{CT}, 6$ - molecular weight marker M-50; b - GHR: 12, 15, 16, 18, 21 - B0, 13, 14, 19, 20, 22 - A0, 17 - M-50; c-GH4(AluI): 23-26, 29, 30, 33 - CT, 27, 31 - TT, 32 - CC, 28 - M-50; d - IGF-I: 34, 40-42, 44 - AC, 35 - AA, 36-38, 43 - CC, 39 - M-50; e - GH4(MspI): $45-$ AA, 46, 47, 49, 53 - AB, 48, 51, 55 - AC, 54 - BB, 50 - molecular weight marker M-100; f - MX: 56, 58, 60, 62 - AG, 57, $59,61,63-65-\mathrm{GG}, 66-\mathrm{AA}$

types and experiment indices due to the insufficient number of chickens for analysis in some cases. Therefore, our tables present only the genotypes, by which it was possible to conduct statistical analysis for both experimental populations of chickens).

The results for the analysis of parameters of egg quality traits for Rhode-Island Red chickens, line 38, depending on the genotype in terms of determined polymorphic loci are presented in Table 1.

By prolactin locus, the analysis of indices was conducted only between chickens with genotypes CT and TT. The results of the study demonstrated the prevail of egg weight parameters for homozygotes with TT genotype. When chickens were 52 weeks old, the difference in terms of this index was significant $(p<0.05)$. Homo- zygous chickens were also noted for higher parameters of egg yolk weight and egg shell weight (Table 1). It is of special interest that in terms of the number of eggs (egg-laying capacity), there was prevalence of heterozygous birds which had been previously demonstrated in our studies on line 38 .

As for AluI-polymorphism in intron 4 of growth hormone gene, there was slight prevail of egg weight index for 30-week-old chickens with genotype CC over $\mathrm{TT}$, but in general, no significant differences were determined.

As for MspI-polymorphism in the intron 4 of growth hormone gene, we analyzed the parameters for birds of all the possible genotypes, but no significant differences were determined. 
KULIBABA et al.

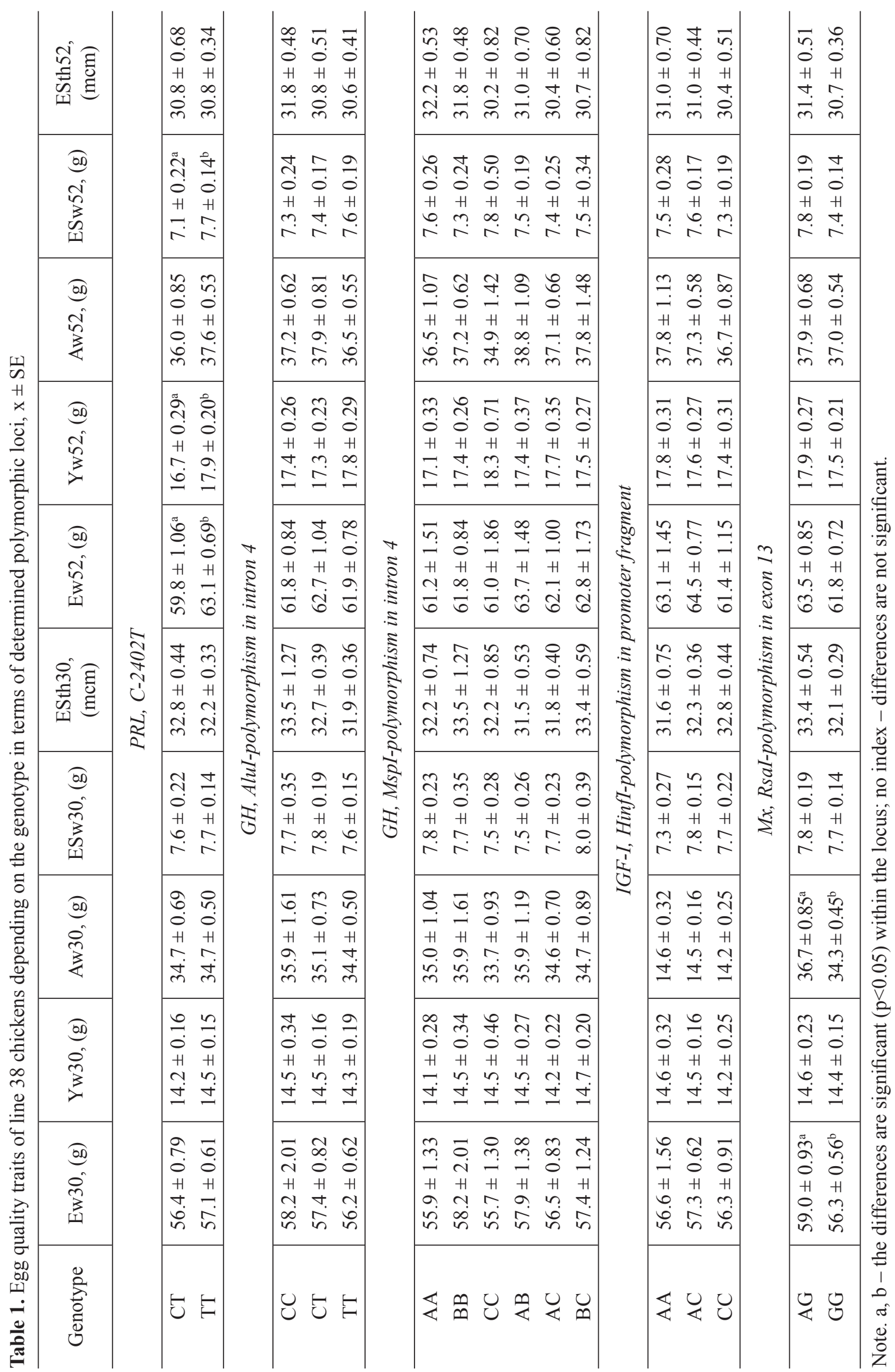


A similar situation was observed in case of polymorphic variants of the insulin-like growth factor I gene.

The situation was completely different for polymorphism of the Mx gene. In this case, we analyzed the parameters of heterozygous chickens AG with homozygotes GG. The results of our studies of egg quality traits for chickens with different genotypes by Mx gene demonstrated that heterozygous chickens were characterized by significantly higher egg and albumen weight in week 30 . The tendency was still there in week 52, but the differences between the various genotypes were not significant (Table 1).

In case of line 14 of Poltava Clay chickens, we also analyzed egg quality traits of chickens with different allelic variants of growth hormone receptor gene. However, the studies were not possible for AluI-polymorphism in intron 4 of growth hormone gene due to insufficient number of chickens with different genotypes for statistical analysis. Only chickens with genotypes $\mathrm{AC}, \mathrm{BC}$ and $\mathrm{CC}$ were analyzed in terms of MspIpolymorphism in intron 4 . The results of studies are presented in Table 2.

The studies demonstrated significant differences by the index of egg weight on the $30^{\text {th }}$ week of life $(p<0.05)$ in prolactin locus. Homozygous individuals CC and TT prevailed in these indices over heterozygotes $\mathrm{CT}$. This tendency was preserved on the $52^{\text {nd }}$ week of life, but the differences between the chickens with different genotypes were within the statistical error.

Significant differences between chickens with genotype $\mathrm{BC}$ and those with other genotypes were determined by MspI-polymorphism in intron 4 of growth hormone gene in terms of egg weight on the $30^{\text {th }}$ week of life. Significant differences in terms of egg weight were also determined on the $52^{\text {nd }}$ week of life, and maximal differences were noted while comparing heterozygotes $\mathrm{BC}$ and homozygous chickens by allele C (Table 2). Significant differences were also demonstrated between chickens with genotypes AC and CC in terms of egg shell thickness.

As for HindIII-polymorphism in intron 2 of growth hormone receptor gene, a significant prevalence of individuals with the $\mathrm{B} 0$ genotype over $\mathrm{A} 0$ by parameters of egg yolk weight was noted at the age of 52 weeks $(\mathrm{p}<0.05)$.

By locus of insulin-like growth hormone factor I gene, no significant differences were found for all the investigated egg quality traits, but as for Mx-gene, sta- tistically significant differences were determined for egg shell thickness on the $52^{\text {nd }}$ week of life $(p<0.05)$.

By parameters of egg form and Haugh units, no significant differences between the chickens with different genotypes were determined for each investigated locus within one line, the parameters were in the range of requirements to chicken assessment. The fluctuations for the egg form index in line 14 of Poltava Clay chickens were within 76.0-78.3; Haugh units on the $30^{\text {th }}$ week of life fluctuated from 91.9 to 95.9 . In line 38 of Rhode-Island Red chickens, the egg form index parameters varied from 77.5 to 79.3 ; Haugh units on the $30^{\text {th }}$ week - from 92.9 to 97.9 ; on the $52^{\text {nd }}$ week of life $-83.3-88.5$.

\section{DISCUSSION}

The attractiveness of prolactin locus as an investigation object in the direction of studying the specificity of variations in egg quality traits is confirmed by many studies, conducted with both commercial and native indigenous chicken breeds. For instance, polymorphism by C-2402T was determined for native Vietnamese chicken breeds, while the frequency of allele $\mathrm{T}$ was prevalent in the experimental populations $(\mathrm{Vu}$ et al, 2016). This fact was also observed in our studies (first of all for dual-purpose Ukrainian chicken breeds) (Kulibaba et al., 2018). Promising mutations were found in the prolactin locus in different functional units of the gene in different breeds, the studies of associations with traits in which have been going on for rather a long time (Li et al., 2013; Osman et al., 2017). The functional relevance of prolactin as a regulator of many physiological functions of the animal organism as well as differences in the productivity direction (egg, meat and dual-purpose chicken breed) give grounds for the explanation of the diversity of the observed alleles which are related with egg-laying capacity. The involvement in the regulation of reproductive functions (egg-laying capacity) may serve as a possible explanation of the fact that during the study on productive traits of chicken lines of different breeds of Ukraine selection, it was prolactin locus to demonstrate the association with production traits practically in all investigated lines.

The genes of growth hormone and growth hormone receptor are more common investigation objects in the context of studying the associations of various genotypes with meat productivity parameters in chicken (Ouyang et al., 2008; Khaerunnisa et al., 2017). Although the relation with egg productivity and egg quality of chickens from different breeds for this gene are 
KULIBABA et al.

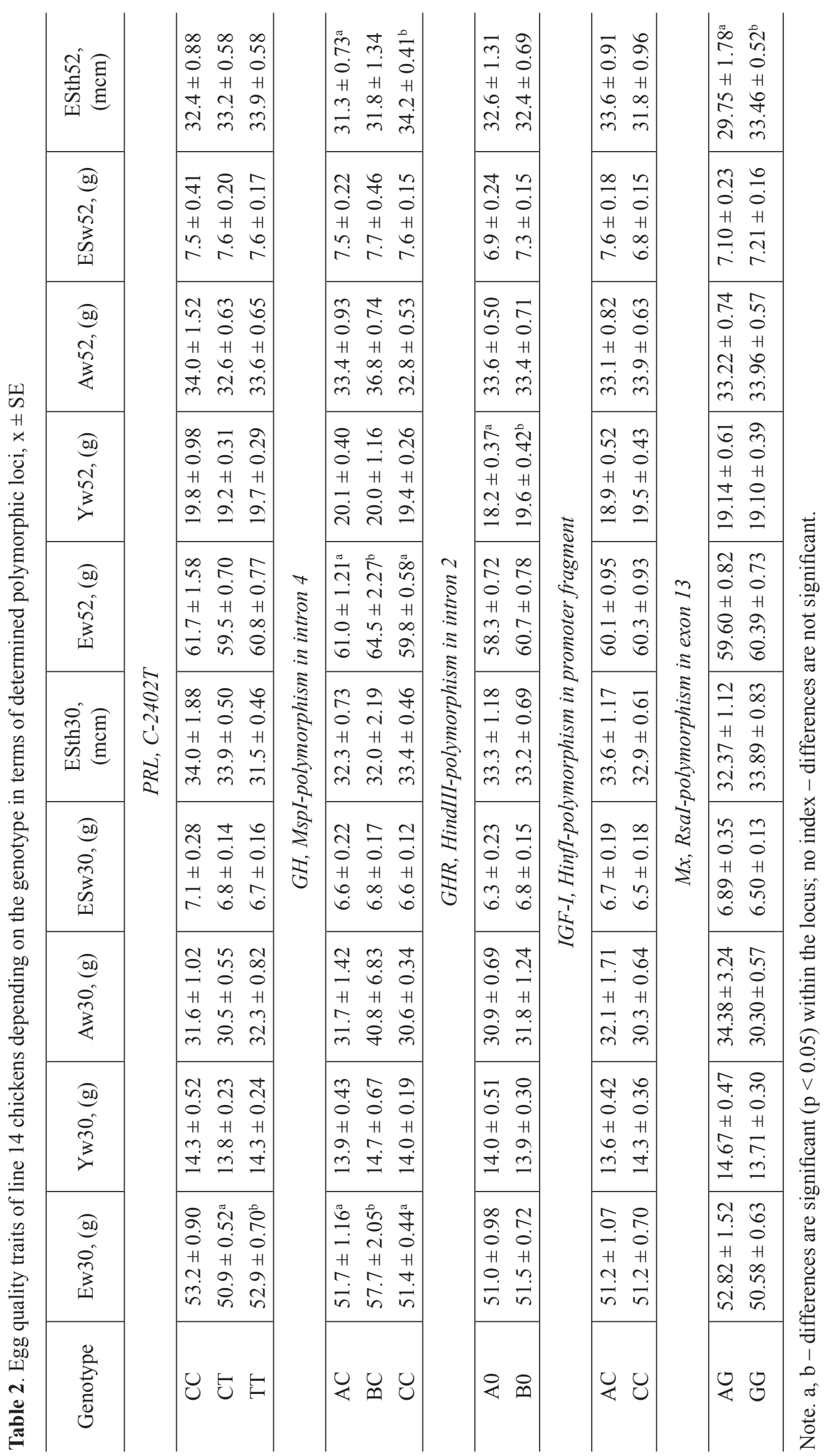


also rather well-studied (Seyyedbabayi et al., 2014; Bal et al., 2020). The results, that obtained in these studies, demonstrate the variations in terms of association with egg quality traits for different experimental lines and breeds of chickens.

A similar situation was found for insulin-like growth factor I gene. In general, its functioning is directly associated with GH and GHR, so they may be viewed as a unified functional system, which is more than justified from a physiological standpoint (Attarchi et al., 2017; Kazemi et al., 2018). However, regardless of perspectives, the phenomenon of potential breed specificity imposes limitations - it is not always possible to determine the association between different alleles of $I G F-I$ and productive traits. The results, obtained using egg-laying hens of Turkish selection, coincide with the data, presented in this article, - no associations between various allelic variants by HinfI-polymorphism in the promoter fragment of $I G F-I$ and egg quality traits were determined (Daş et al., 2018).

While analyzing the polymorphism of Mx-gene (mutation $\mathrm{S} 631 \mathrm{~N}$ ) in both experimental populations of chickens, it was possible to analyze the association between different allelic variants and egg quality traits only for homozygotes GG and heterozygotes AG due to the specificities of genetic-populational structure. The absence of homozygotes AA in the experimental populations of chickens may be explained by the association of allele A and the resistance to diseases (first of all, to Marek's disease), and between allele $\mathrm{G}$ and higher indices of egg-laying capacity (the number of laid eggs), which may have played its decisive role at the stage of line formation. However, allele A was preserved in both populations, which may have become possible due to the impossibility of dividing the animals by genotypes based on the phenotypic assessment. The regularity of prevalence of the frequency of allele $G$ incidence in the population is generally notable for different commercial lines and breeds, the breeding work in which is conducted, first of all, with the purpose of enhancing egg-laying capacity (Susanti et al., 2017). However, a rather high, close to prevalence, frequency of allele A incidence is observed in local indigenous breeds of chickens (Pagala et al., 2017). Regardless of prevalent interest of scientists to the issues of resistance, some studies on the association between the alleles of Mxgene and productive traits were also conducted. For instance, by parameters of egg-laying capacity, a positive association between allele $\mathrm{G}$ and egg-laying capacity was determined in populations of Indonesian chickens, but no significant differences were found in terms of egg weight (Sartika et al., 2011). Our studies determined the association between allele $\mathrm{G}$ and enhanced egg-laying capacity of chickens (number of eggs) and demonstrated the prevalence of heterozygous birds of line 38 for egg and albumen weight (Table 1).

Therefore, summing up the mentioned above, the results of the study demonstrate that there is a relation between the prolactin gene (transition C-2402T) of both lines of chickens of dual-purpose productivity direction and parameters of egg quality, i.e. there were differences in parameters for chickens with different genotypes. The loci of growth hormone (MspIpolymorphism in intron 4), growth hormone receptor and Mx-gene demonstrated breed specificity ( $G H$ and GHR for line 14, $M x$ - for line 38). When results of this study with previous ones are compared the following regularity can be observed: - lower parameters of egg weight were registered for chickens with different genotypes by different polymorphic loci (in this case it was prolactin locus and $\mathrm{Mx}$-gene) that were notable for prevalence in the number of laid eggs. This fact is in good agreement with the general biological paradigm that for effective selection work not only marker genotypes but and specific tasks of the breeding work have to be taken into consideration (for instance, breeding to enhance egg-laying capacity or egg weight).

\section{CONCLUSIONS}

We have analyzed the relation of egg quality traits of Poltava Clay chicken line 14 and Rhode-Island Red chicken line 38 with different genotypes of the prolactin loci (transition C-2402T), growth hormone (AluI and MspI-polymorphism in intron 4), growth hormone receptor (HindIII-polymorphism in intron 2), insulin-like growth hormone factor I gene (HinfI-polymorphism in promoter fragment) and Mx gene (mutation S631N). Significant differences $(p<0.05)$ for egg quality indices by prolactin loci, growth hormone (MspI-polymorphism), growth hormone receptor and Mx gene were determined in the study results for Poltava Clay chicken line 14. There were significant differences in egg quality traits by prolactin and Mx gene loci for Rhode-Island Red chickens, line 38. No significant differences were determined in the investigated parameters of chickens with different genotypes by the remaining polymorphic loci. The results of our study may be used for elaboration of the breeding programs in marker-assisted selection of dual-purpose Ukrainian chicken lines. 
Adherence to ethical principles. All procedures performed in the studies involving animal participants were in accordance with the European Convention for the Protection of Vertebrate Animals used for Experimental and Other Scientific Purposes, Strasbourg, 1986.

Conflict of interests. The authors declare the absence of any conflicts of interests.

Financing. This study was not financed by any specific grant from financing institutions in the state, commercial or non-commercial sectors.

\section{Асоціації поліморфізму функціональних генів 3 показниками якості яєць у популяціях курей комбінованого напряму продуктивності української селекції}

Р. О. Кулібаба, М. І. Сахацький, Ю. В. Ляшенко, П. С. Юрко, Ю. В. Осадча

${ }^{1}$ Національний університет біоресурсів і природокористування України, вул. Героїв Оборони 15, Київ, 03041, Україна

${ }^{2}$ Інститут тваринництва Національної академії аграрних наук України, вул. Тваринників 1-А, Харків, 61026, Україна

${ }^{3}$ Харківська державна зооветеринарна академія Міністерства освіти і науки України, вул. Академічна 1, смт. Мала Данилівка, 62341, Україна

E-mail: romankx37@gmail.com*,mik99@ukr.net, yurij2303@gmail.com, yurkopolina81@gmail.com, seledat@ukr.net

Мета. Дослідження показників якості яєць курей лінії 14 породи полтавська глиняста та лінії 38 породи род-айленд червоний різних генотипів за локусами пролактину $(P R L)$, гормона росту $(G H)$, рецептора гормона росту $(G H R)$, інсуліноподібного ростового фактора I (IGF-I), гена Мx $(M x)$. Методи. Дослідження проводили 3 використанням методу полімеразної ланцюгової реакції та рестрикційного аналізу (PCR-RFLP). Результати. За результатами досліджень у лінії 14 виявлено вірогідну різницю за показниками якості яєць за локусами пролактина, гормона росту, рецептора гормона росту та Мх гена. За локусом пролактина гомозиготні особини $\mathrm{CC}$ та ТТ за показником маси яйця на 30 тиждень життя превалюють за значеннями над гетерозиготами СТ. За геном гормона росту максимальну різницю виявлено за масою яйця за порівнянням гетерозигот ВС та гомозигот СС. За геном рецептора гормона росту відмічено вірогідне превалювання $(\mathrm{p}<0.05)$ особин 3 генотипом В0 над А0 за показником маси жовтка на 52 тиждень життя. За геном Мх виявлено статистично вірогідні розбіжності $(\mathrm{p}<0.05)$ між особинами 3 генотипами AG та GG за значенням товщини шкаралупи на 52 тиждень життя. Для курей лінії 38 показано вірогідну різницю $(\mathrm{p}<0.05)$ за показниками якості яєць за локусами пролактина та гена Мх. За локусом пролактина для гомозигот ТТ $є$ характерним превалювання значень $(\mathrm{p}<0.05)$ за масою яйця, жовтка та шкаралупи. За геном Мх гетерозиготні особини характеризуються вірогідно більшими значеннями $(\mathrm{p}<0.05)$ маси яйця та білка на 30 тиждень життя. За всіма іншими локусами в обох дослідних лініях курей вірогідної різниці за значеннями показників якості яєць між особинами 3 різними генотипами не виявлено. Висновки. Отримані за результатами досліджень дані стосовно асоціацій різних генотипів за виявленими поліморфними локусами 3 показниками якості яєць курей лінії 14 породи полтавська глиняста та лінії 38 породи род-айленд червоний рекомендовано використовувати у програмах селекційної роботи 3 метою отримання мікроліній з різними генотипами за локусами PRL, GH, GHR та Mx.

Ключові слова: поліморфізм, пролактин, популяція, кури, ген, алель, продуктивність, якість яєць.

\section{REFERENCES}

Ahmadi S, Takeda M, Ohkubo T. (2019) Determination of Polymorphisms in Pituitary Genes of the Native Afghani Naked Neck Chicken. J. Poultry Sci. 56(4):253-61. doi: 10.2141/ jpsa.0180087.

Alipanah M, Shojaian K, Bandani HK. (2010) The polymorphism of prolactin gene in native chicken Zabol region. J. Anim. Veterin. Advan. 9(24):3005-7. doi: 10. 3923/javaa.2011.619.621.

Attarchi H, Tahmoorespur M, Ahani Azari M et al. (2017) Allelic Polymorphism of GH, GHR and IGF-1 Genes and Their Association with Growth and Carcass Traits in Mazandaran Native Fowl. Poult. Sci. J. 5(1):25-30. doi: 10.22069/psj.2017.11520.1200.

Bal GR, Vishesh KS, Usha R et al. (2020) PCR-RFLP Study of Candidate Genes for Egg Production in Layer Chicken. Arch. Anim. Poult. Sci. 1(3):52-8.

Bello SF, Akinyemi MO, Fatai RB et al. (2020) Detection of Polymorphism of Pituitary Specific Transcription Factor 1 Gene and Its Association with Bodyweight of Fulani and Yoruba Ecotype Chickens. Open J.Anim. Sci.10:278-86. doi: 10.4236/ojas.2020.102016.

Bhattacharya TK, Chatterjee RN, Sharma RP et al. (2011) Association of polymorphism in the prolactin promoter and egg quality traits in laying hens. Brit. Poult. Sci. 52(5):551-7. doi: 10.1080/00071668.2011.617727.

Boschiero C, Moreira GCM, Gheyas AA et al. (2018) Genome-wide characterization of genetic variants and putative regions under selection in meat and egg-type chicken lines. BMC Genet. doi: 10.1186/s12864-018-4444-0.

Chethan RR, Kanaka KK, Jeevan C et al. (2018) A review on polymorphism in egg production linked genes in poultry. J. Entomol. Zool. Stud. 6(5):2342-5.

Daş H, Tarim B, Demir S et al. (2018) Association of IGF and IGFBP2 gene polymorphisms with growth and egg 
traits in Atak-S laying hens. J. Hellen. Veterin. Med. Society 68(2):237-242. doi:10.12681/jhvms. 15611

Dementeva NV, Vakhrameev AB, Larkina TA et al. (2019) Efficiency of using SNP markers in the MSTN gene in the selection of the Pushkin breed chickens. Vavilov J. Genet. Breed. 23(8):993-8. doi: 10.18699/VJ19.575.

Esmailnejad A, Brujeni GN. (2018) Allelic polymorphism of insulin-like growth factor I gene and its association with production traits in native chickens. Bulgar. J. Veterin. Med. 21(3):279-85. doi: 10.15547/bjvm.1072.

Feng XP, Kuhnlein U, Aggrey SE et al. (1997) Trait association of genetic markers in the growth hormone and the growth hormone receptor gene in a White Leghorn strain. Poult. Sci. 76:1770-5. doi: 10.1093/ps/76.12.1770.

Heba, Shafey I, Aboelhassan MD et al. (2017) SNP of cGH Gene in Egyptian Chicken Breeds at MspI site. Biosci. Biotechnol. Res. Asia 14(1):33-41. doi:10.13005/bbra/2414.

Kazemi H, Rezaei M, Hafezian H et al. (2018) Genetic Analysis of SNPs in GH, GHR, IGF-I and IGFBPII Genes and their Association with Some Productive and Reproductive Traits in Native Breeder Hens. Gene Technol. doi: 10.4172/2329-6682.1000145.

Khadem A, Hafezian H, Rahimi-Mianji G. (2010) Association of single nucleotide polymorphisms in IGF-I, IGF-II and IGFBP-II with production traits in breeder hens of Mazandaran native fowls breeding station. Afr. J.Biotechnol. 9(6):805-10. doi: 10.5897/AJB09.1231.

Khaerunnisa I, Jakaria, Arief II et al. (2017) The Associations of GH and GHR Genes with Carcass Components in Indonesian Kampung and Broiler Chicken Cross. Media Peternakan. 40(2):78-87. doi: 10.5398/ medpet.2017.40.2.7.8

Kulibaba RO. (2016) A distribution of GHR-alleles in chicken populations of different breeds. Scientific and Technical Bulletin of the Institute of Animal Science of the National Academy of Agrarian Science of Ukraine 116:54-61. In Ukrainian.

Kulibaba RA, Liashenko YV, Yurko PS. (2018) Genetic differentiation of Ukrainian chicken breeds using various types of molecular genetic markers. Agric. Biol. 53(2):282-92. doi:10.15389/agrobiology.2018.2.282eng.

Kulibaba RO. (2017) Molecular-genetic markers using for selection work in populations of local Ukrainian chicken breeds. Scientific and Technical Bulletin of the Institute of Animal Science of the National Academy of Agrarian Science of Ukraine. 118:104-13. In Ukrainian.

Kulibaba RA, Liashenko YV, Yurko PS. (2017) Novel AluIpolymorphism in the fourth intron of chicken growth hormone gene. Cytol. Genet. 51:54-9. doi: 10.3103/ S0095452717010091

Li HF, Shu JT, Du YF et al. (2013) Analysis of the genetic effects of prolactin gene polymorphisms on chicken egg production. Mol. Biol. Rep. 40:289-94. doi: 10.1007/ s11033-012-2060-7.
Li JJ, Zhang L, Ren P et al. (2020) Genotype frequency distributions of $28 \mathrm{SNP}$ markers in two commercial lines and five Chinese native chicken populations. BMC Genetics. doi: 10.1186/s12863-020-0815-z.

Luan DQ, Chang GB, Sheng ZW et al. (2010) Analysis on the polymorphism and the genetic effects on some economic traits of MX gene S631N mutation site in chicken. Thai J. Vet. Med. 40(3):303-10.

Osman MMM, Hemeda SA, Hassanin AAI et al. (2017) Polymorphism of Prolactin Gene and Its Association with Egg Production Trait in Four Commercial Chicken Lines. J. Hellen. Veterin. Med. Soc. 68(3):391-404. doi: 10.12681/jhvms. 15502 .

Ouyang JH, Xie L, Nie $Q$ et al. (2008) Single nucleotide polymorphism (SNP) at the GHR gene and its associations with chicken growth and fat deposition traits. British Poult. Sci. 49(2):87-95. doi: 10.1080/00071 660801938817.

Pagala MA, Saili T, Nafiu LO et al. (2017) Polymorphism of Mx|Hpy81 Genes in Native Chickens Observed using the PCR-RFLP Technique. International J. Poult. Sci. 16:364-8. doi: 10.3923/ijps.2017.364.368.

Sartika T, Sulandari S, Zein MSA. (2011) Selection of Mx gene genotype as genetic marker for Avian Influenza resistance in Indonesian native chicken. BMC Proceedings. doi: 10.1186/1753-6561-5-S4-S37.

Seyyedbabayi M, Seyedabadi H, Gorbani A et al. (2014) Growth hormone receptor gene polymorphism and its associations with some growth traits in West-Azarbaijan native chicken. Bull. Environ., Pharmacol. Life Sci. 3(6): 140-3.

Simrinder SS, Jeong DK, Sharma $N$ et al. (2013) Marker assisted selection - applications and evaluation for commercial poultry breeding. Korean J. Poult. Sci. 40(3):223-34. doi: 10.5536/KJPS.2013.40.3.223.

Susanti R, Utami NR, Rahayuningsih $M$ et al. (2017) Identification of Avian Influenza Genetic Resistance Gene Marker in Chickens. Makara J. Sci. 24(17):169-174. doi: 10.7454/mss.v21i4.7428

Tsarenko PP. (1988) Improving the Quality of Poultry Products: Food and Hatching Eggs. Leningrad, USSR: Agropromizdat, Leningrad Branch. (In Russian).

Vu CT, Ngu NT. (2016) Single Nucleotide Polymorphisms in Candidate Genes Associated with Egg Production Traits in Native Noi Chicken of Vietnam. Inter. J. Plant, Anim.. Environ. Sci. 6(1):162-9.

Wolc A, Kranis A, Settar P et al. (2016) Implementation of genomic selection in the poultry industry. Anim. Front. 6(1):23-31. doi: 10.2527/af.2016-0004.

Xu LY, Zhao FP, Sheng XH et al. (2012) Optimal design for marker-assisted gene pyramiding in cross population. Asian-Australasian J. Anim. Sci. 25(6):772-84. doi: 10.5713/ajas.2011.11239. 